\title{
Sistem Kontrol Pengering Makanan Berbasis LED Inframerah
}

\author{
Khairunnisa Nurhandayani, dan Muhammad Rivai \\ Departemen Teknik Elektro, Fakultas Teknologi Elektro, Institut Teknologi Sepuluh Nopember (ITS) \\ e-mail:muhammad_rivai@ee.its.ac.id
}

\begin{abstract}
Abstrak-Hasil perkebunan seperti buah dan sayur merupakan bahan yang memiliki kandungan air. Namun dengan banyaknya kandungan air menyebabkan buah dan sayur tidak dapat bertahan lama di tempat terbuka. Salah satu cara mengawetkan buah dan sayur tersebut dilakukan dengan proses pengeringan. Pengeringan merupakan cara menghilangkan air dalam makanan untuk memperlambat pertumbuhan mikroorganisme. Pada penelitian ini, pengeringan dilakukan terhadap biji coklat karena Indonesia negara pengekspor biji coklat. Sebelum diekspor, biji coklat terlebih dahulu difermentasi untuk menghasilkan aroma khas coklat dan dilakukan proses pengeringan untuk menghentikan fermentasi pada biji coklat. Jika menggunakan pengering konvensional, hasil pengeringan terlalu bergantung terhadap cuaca atau matahari. Oleh karena itu dibutuhkan suatu sistem pengering makanan yang tidak bergantung terhadap cuaca atau matahari dengan penggunaan daya yang realistis. Pada penelitian ini telah dirancang dan diuji sistem pengering berbasis inframerah. LED bank digunakan sebagai sumber sinar inframerah dengan merangkai LED inframerah secara seri dan paralel. Untuk mengetahui perubahan kandungan air yang terjadi pada biji coklat digunakan load cell yang keluarannya dimasukkan ke mikrokontroler untuk diolah lebih lanjut dengan sistem kontrol proportional. Mikrokontroler yang digunakan yaitu Arduino Uno. Selain biji coklat, objek yang diujikan yaitu anggur. Hasil penelitian menunjukkan kecepatan pengeringan biji coklat lebih besar dibandingkan kecepatan pengeringan anggur. Kecepatan pengeringan anggur yaitu 0,27 gram/jam setiap pengeringan 4 hingga 7-gram dan kecepatan pengeringan biji coklat bernilai 0,75 gram/jam untuk berat yang sama. Dari hasil tersebut diharapkan sistem ini menghasilkan pengeringan yang lebih cepat dibandingkan dengan pengeringan konvensional.
\end{abstract}

Kata Kunci- LED Inframerah, Sistem Kontrol Proportional, Sistem Pengering.

\section{PENDAHULUAN}

$\mathrm{H}$ ASIL perkebunaan seperti buah dan sayur merupakan bahan yang selain mengandung banyak vitamin juga kaya akan kandungan air. Namun dengan banyaknya kandungan air menyebabkan buah dan sayur tidak dapat bertahan lama. Pada umumnya untuk mengawetkan buah dan sayur dilakukan pendinginan dan pengeringan. Pendinginan dilakukan tanpa perlu mengubah bentuk buah dan sayur. Sedangkan pengeringan dapat mengubah bentuk buah dan sayur. Pengeringan merupakan salah satu cara pengawetan makanan dengan cara menghilangkan air untuk memperlambat pertumbuhan mikroorganisme pengurai.

Indonesia merupakan salah satu negara pengekspor buah coklat. Pada tahun 2015, ekspor coklat atau kakao menyumbangkan devisa USD 1,01 milyar atau 3,78\% dari keseluruhan ekspor komoditas perkebunan dimana 28,79\% berupa biji coklat dan menduduki peringkat penyumbang devisa terbesar ke lima. Pada periode 2011 - 2015, Indonesia menduduki peringkat ke 11 dengan kontribusi $2,73 \%$ dari total ekspor dunia dan data ekspor dapat dilihat pada Tabel 1 [1]. Untuk perkembangan luas area kebun coklat di Indonesia dalam kurun waktu 1980 - 2016 umumnya meningkat dengan rata - rata $11,48 \%$ per tahun dan hasil produksi coklat Indonesia juga mengalami peningkatan 13,99 \% per tahun [2]. Sebelum diekspor, biji coklat terlebih dahulu difermentasi dan dikeringkan. Pengeringan biji coklat dilakukan untuk mengurangi kelembapan atau kandungan air dari $50 \%$ menjadi $7 \%$. Lama pengeringan dengan cara konvensional membutuhkan waktu sekitar tiga hingga delapan hari.

Selain biji coklat, hasil perkebunan yang ada di Indonesia yaitu anggur. Anggur merupakan tanaman buah-buahan yang dapat dipanen lebih dari satu kali dalam setahun. Produksi anggur mengalami peningkatan pada tahun 2015 dengan berat 11.146 ton menjadi 11.410 ton [3]. Di Indonesia sendiri anggur merupakan salah satu jenis buah yang diekspor. Namun, anggur yang diekspor baru dalam bentuk buah segar saja. Untuk anggur yang dikeringkan menjadi kismis membutuhkan waktu 15 hingga 20 hari penjemuran. Selain pengeringan yang lama, kismis hasil penjemuran yang dihasilkan akan terkena debu atau benda asing lain yang mungkin akan sulit dibersihkan.

Tabel 1.

Negara Eksportir Kakao (Coklat) Terbesar Dunia, 2011 - 2015

\begin{tabular}{clrrrr}
\hline \hline No. & Eksportir & \multicolumn{2}{c}{ Nilai Ekspor (000 USD) } & Rata - Rata & $\begin{array}{c}\text { Share } \\
(\%)\end{array}$ \\
\cline { 3 - 6 } & & \multicolumn{1}{c}{2014} & 2015 & & \\
\hline 1 & Jerman & 6022452 & 5371434 & 5295453 & 11.76 \\
2 & Belanda & 5463094 & 4665559 & 4795881 & 10.65 \\
3 & Pantai & 4627478 & 4661837 & 3989219 & 8.86 \\
& Gading & 3447538 & 3427746 & 3184709 & 7.07 \\
4 & Belgia & 2396536 & 2168056 & 2285725 & 5.08 \\
5 & Perancis & 3018451 & 2444685 & 2250396 & 5.00 \\
6 & Ghana & 2117069 & 1942857 & 1848028 & 4.10 \\
7 & USA & 1787105 & 1637587 & 1663600 & 3.70 \\
8 & Italia & 848199 & 391536 & 1637820 & 3.64 \\
9 & Nigeria & 1647253 & 1558605 & 1415037 & 3.14 \\
10 & Polandia & 1244530 & 1307771 & 1220532 & 2.71 \\
11 & Indonesia & 16930979 & 15693747 & 15436476 & 34.29 \\
& Lainnya & 49550684 & 45271420 & 45022877 & 100.00 \\
\hline \hline
\end{tabular}


Beberapa pengujian telah dilakukan. Salah satunya yaitu pengujian keefektifan pengering dengan metode hot air drying, inframerah, dan hot air yang dikombinasi dengan inframerah. Dari pengujian tersebut, waktu pengeringan tercepat adalah pengeringan dengan menggunakan pengering inframerah dan pengering hot air dikombinasi dengan inframerah [4]. Selain itu juga terdapat pengujian pengeringan dengan metode low pressure superheated steam, low pressure superheated steam dengan inframerah, vakum, dan vakum dengan inframerah terhadap pisang. Pengujian tersebut menghasilkan data yaitu dalam temperatur yang sama, kecepatan pengeringan pada pisang dengan metode vakum dengan inframerah lebih besar dibandingkan dengan yang lain [5]. Dari dua pengujian tadi menunjukkan bahwa dibutuhkan suatu sistem pengering yang dapat mengoptimalkan sistem pengering dengan sumber pengering yaitu inframerah. Bentuk dari sumber pengering dari sistem pengering adalah LED bank. Selain karena memiliki panjang gelombang pendek, penggunaan sinar inframerah sendiri dipilih karena ketika objek diberikan sinar inframerah, molekul pada objek akan bergetar sehingga menghasilkan panas [6]. Kualitas dari hasil pengeringan dilihat dari perubahan warna dan rehydration. Pengering inframerah memberikan efek perubahan warna yang tidak signifikan dan peningkatan proses rehydration [5]. Nutrisi dari makanan yang dikeringkan tidak mengalami perubahan karakteristik kualitas seperti vitamin, protein dan antioksidan sehingga aman dikonsumsi [7].

\section{METODE PENELITIAN}

\section{A. Diagram Blok Sistem}

Sistem pengering ini terdiri dari perangkat keras dan perangkat lunak. Perangkat keras yang digunakan dalam sistem yaitu Arduino Uno, load cell, LED bank, LM35, rangkaian PWM driver, supply regulator, dan kipas. Sedangkan perangkat keras yang dapat menunjang sistem adalah desain prototype. Untuk perangkat lunak yang digunakan yaitu program hasil pembacaan ADC dan kalibrasi load cell, pengkompensasian load cell dengan LM35, pembangkit PWM serta sistem kontrol PID. Diagram blok dari sistem tersebut dapat di lihat pada Gambar 1.

\section{B. LED Bank}

Sumber inframerah yang digunakan menggunakan LED bank. LED (Light-Emitting Diode) bank merupakan rangkaian listrik yang terdiri dari banyak LED. LED sendiri adalah komponen semikonduktor yang dapat memancarkan cahaya ketika arus listrik dilewatkan pada komponen tersebut. LED memiliki beberapa keunggulan dibandingkan dengan sumber cahaya dari beberapa jenis lampu seperti dapat dipakai dalam jangka waktu yang lama, ukuran yang kecil, dan respons yang cepat. LED bank terdiri dari LED inframerah yang disusun secara matriks atau dibuat array. Pada rancangan pemancar inframerah ini akan disusun LED inframerah secara matriks yaitu $10 \times 10$ di setiap papan rangkaian LED Bank dengan jarak masing - masing LED 5 $\mathrm{mm}$. Rangkaian LED inframerah akan dirangkai secara seri dan paralel. LED yang digunakan yaitu IR333C dengan tegangan forward bernilai 1,2 V ketika arus forward $20 \mathrm{~mA}$ dan $1,4 \mathrm{~V}$ ketika arus forward $100 \mathrm{~mA}$. Rancangan dari pemancar inframerah dapat dilihat pada Gambar 2.

\section{PWM Driver}

PWM merupakan metode yang digunakan untuk membangkitkan sinyal analog dengan menggunakan sumber digital. Sinyal PWM terdiri dari dua komponen utama yaitu duty cycle dan frekuensi..Sedangkan PWM driver memiliki fungsi untuk menginialisasi dan mengontrol perangkat keras PWM dari mikrokontroler [8]. Pada penelitian ini, sumber PWM diambil dari Arduino Uno yang digunakan sebagai masukan MOSFET IRF530. IRF 530 digunakan sebagai pengatur arus yang melewati LED bank.
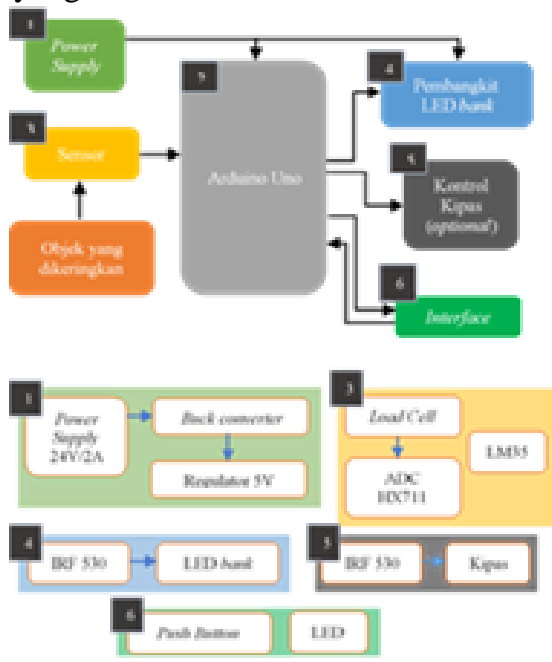

Gambar 1. Diagram Blok Sistem Kontrol Pengering Makanan Berbasis LED Inframerah.

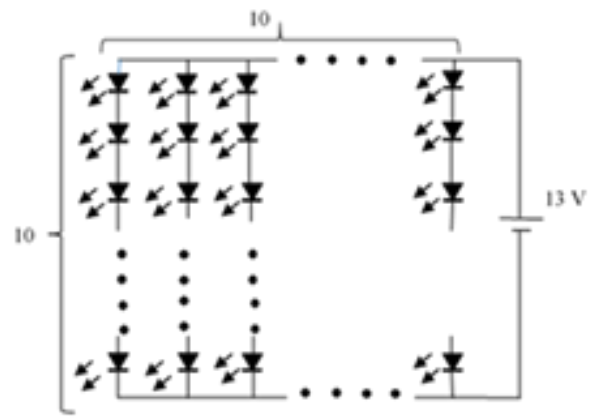

Gambar 2. Rangkaian LED Bank yang terdiri dari LED Inframerah yang Disusun Seri dan Paralel.

\section{Strain Gauge Load Cell}

Load cell merupakan sensor yang menghasilkan keluaran berupa sinyal listrik yang berubah ketika gaya atau berat diberikan [9], [10]. Strain gauge merupakan resistan listrik yang dibuat sebagai pola kawat paralel atau foil logam tipis yang tertanam ke dalam isolasi berbahan plastk. Load cell yang digunakan pada penelitian ini berjenis shear beam. Pemasangan load cell dilakukan pada kondisi tempat yang 
datar dan berada pada tengah bagian dasar protoype seperti Gambar 3 .

\section{E. Modul HX711}

Modul HX711 digunakan sebagai Analog-to-Digital Converter (ADC) yang mengonversi sinyal dari load cell agar dapat terbaca oleh Arduino Uno. Pada HX711 terdapat channel A dan channel B sebagai analog input dengan bentuk differential input. Channel A memiliki penguatan 128 kali atau 64 kali. Sedangkan channel B memiliki hanya satu penguatan yaitu 32 kali. Komunikasi antar HX711 dengan Arduino Uno menggunakan pin SCK dan pengiriman data melalui pin DOUT.

\section{F. Sensor Temperatur}

Sensor temperatur mengubah energi panas menjadi sinyal listrik. Pengaplikasian sensor ini dapat dilakukan dengan beberapa cara yaitu konduksi, konveksi, dan radiasi. Dioda dan transistor bipolar merupakan salah satu komponen yang dapat digunakan sebagai sensor ini yang ketergantungan terhadap temperatur cukup tinggi [11]. Sensor temperatur memiliki fungsi sebagai kompensasi terhadap load cell karena semakin meningkat temperature, semakin berubah nilai pembacaan load cell. Sensor temperatur yang digunakan yaitu LM35D.

\section{G.Buck Converter}

Buck converter digunakan sebagai penurun tegangan dari power supply. Keluaran dari buck converter kemudian disambungkan dengan masukan ke LED bank. Besar tegangan keluaran dari buck converter yang digunakan adalah $13 \mathrm{~V}$ dengan cara memutar resistor multiturn. Untuk tipe IC (Intergrated Circuit) yang digunakan adalah XL4005E1.

\section{H.Regulator Tegangan}

Keluaran dari buck converter dijadikan sebagai masukan regulator tegangan. Besar nilai regulator tegangan yang dihasilkan yaitu $5 \mathrm{~V}$ dan $12 \mathrm{~V}$. Tegangan yang dihasilkan regulator akan digunakan untuk menjalankan kipaa, HX711, dan Arduino Uno. IC regulator yang digunakan yaitu LM7805 dan LM 7812 dengan tegangan masukan maksimal adalah $35 \mathrm{~V}$.

\section{Sistem Kontrol Proportional}

Sistem kontrol proportional merupakan sistem kontrol yang digunakan pada sistem pengering ini. Kontrol proportional bersifat proposional terhadap eror kontrol dari keluaran sesuai dengan (1)

$$
u(t)=K_{p} e(t)=K_{p}(r(t)-y(t))
$$

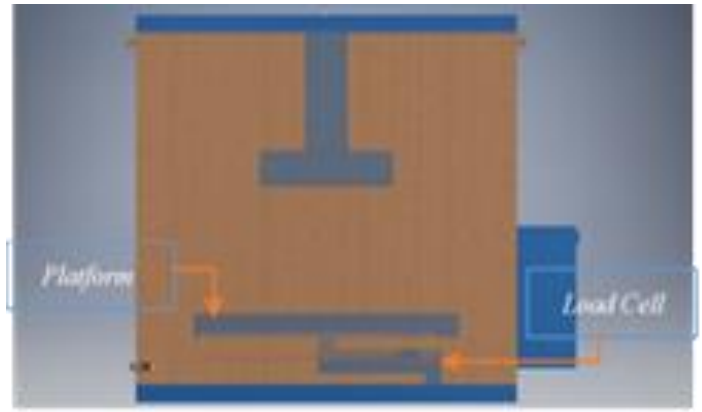

Gambar 3. Penempatan Load Cell.

dengan $\mathrm{K}_{\mathrm{p}}$ sebagai penguatan proporsional dan $\mathrm{e}(\mathrm{t})$ sebagai eror kontrol.Pada sistem kontrol ini, nilai set point merupakan niilai presentase kandungan air pada objek yang dipanaskan dan ditentukan dengan (2)

Besar aîr yang dippindahkan $=\frac{\text { Berat awal objek }- \text { Berat objek akhĩr }}{\text { Berat awal objek }}$

Kemudian dilakukan penentuan nilai Kp dengan aturan Ziegler-Nichols metode satu yaitu memberikan respon step up ke dalam plant dan menemukan nilai $\mathrm{L}$ dan $\mathrm{T}$ dari keluaran yang dihasilkan. Beberapa penggunaan sistem kontrol ini yaitu pemotong Styrofoam [12] dan pengontrol temperatur pada penggentifikasian suara cracking pada pembakaran biji kopi [13].

\section{J. Arduino Uno}

Arduino Uno merupakan salah satu mikrokontroler singleboard berbasis ATmega328 yang bersifat yang dapat memudahkan pengguna untuk mengetahui dan mengembangkan cara kerja perangkat tersebut [14]. Pada penelitian ini, Arduino Uno digunakan sebagai sebagai pengolah data dari load cell dan LM35D, penghasil sinyal PWM dan tempat terjadinya proses kontrol. Sebagai contoh penggunaan Arduino Uno adalah sistem kontrol pengeruhan akuarium [15] dan pembacaan meteran air dimana ArduinoUno digunakan sebagai prosesor data dari node sensor [14], dan pembacaan frekuensi pada deteksi jalur pipa terpendam [16].

\section{HASIL DAN DISKUSI}

\section{A. Pengujian LED Bank}

Pengujian terhadap LED yang perlu dilakukan. Dari hasil pengujian dengan spectrometer, cahaya inframerah yang di pancarakan memiliki intensitas rendah dan menduduki panjang gelombang antara 800 hingga $900 \mathrm{~nm}$. Kemudian LED bank diuji untuk menentukan pilihan terbaik antara 100 buah atau 200 buah LED. Pada Gambar 4, kecepatan pengeringan terbaik diperoleh dengan 200 buah LED. Hal ini dapat terjadi karena intensitas inframerah yang dihasilkan lebih besar dibandingkan dengan 100 LED. Selanjutnya dilakukan pengambilan data terhadap anggur dan biji coklat. Hasil dari pengujian dapat dilihat pada Gambar 5 dan 
Gambar 6. Dari gambar tersebut, kecepatan pengeringan biji coklat lebih cepat dibandingkan dengan anggur untuk berat yang sama. Hal ini disebabkan karena anggur memiliki ketebalan yang lebih besar dibandingkan dengan ketebalan biji coklat. Selain itu, temperatur yang dihasilkan sesuai dengan kecepatan pengeringan Kemudian juga dilakukan pengujian dengan tegangan serta jarak yang diubah-ubah. Hasil Pengujian dapat dilihat pada Gambar 7 dan Gambar 8. Hasil yang didapatkan yaitu semakin besar tegangan sumber, semakin besar pengurangan yang terjadi. Tegangan $13 \mathrm{~V}$ menjadi sumber tegangan yang paling optimal dibandingkan dengan dua sumber tegangan yang lain. Sedangkan jika dilihat dari perubahan jarak, diantara jarak $6 \mathrm{~cm}, 5 \mathrm{~cm}$, dan 4 $\mathrm{cm}$, jarak $6 \mathrm{~cm}$ menunjukkan pengaturan yang lebih besar.

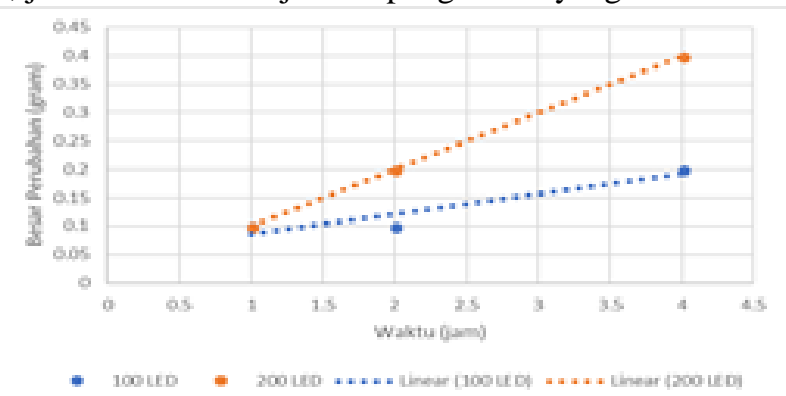

Gambar 4. Kecepatan Pengeringan 100 LED dan 200 LED terhadap Anggur.

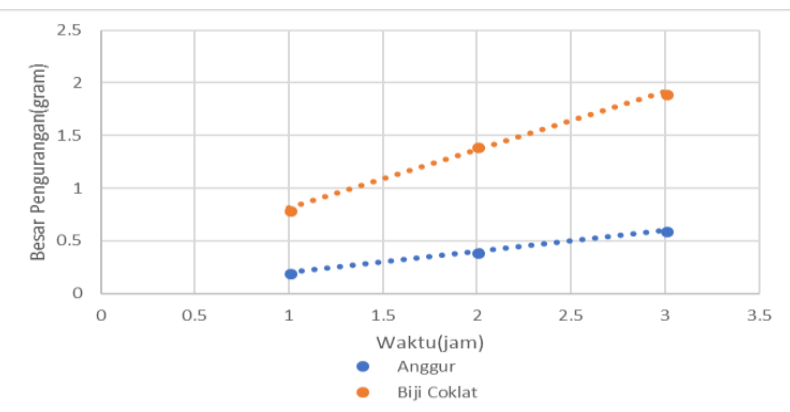

Gambar 5. Perbandingan Hasil Kecepatan Pengeringan Anggur dan Biji Coklat.

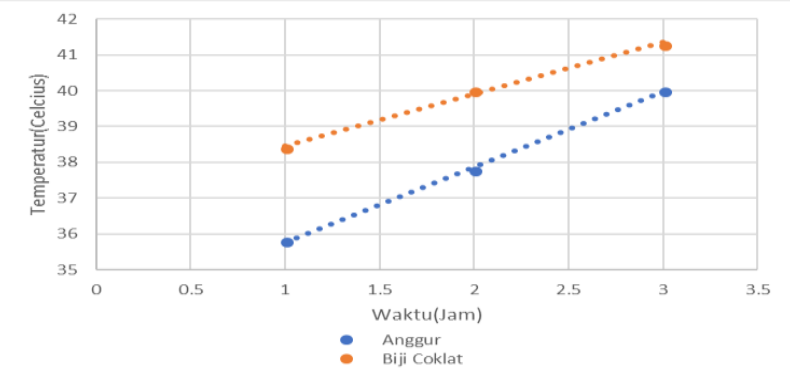

Gambar 6. Perbandingan Temperatur yang Dihasilkan dari Pengeringan Anggur dan Biji Coklat dengan 200 LED.

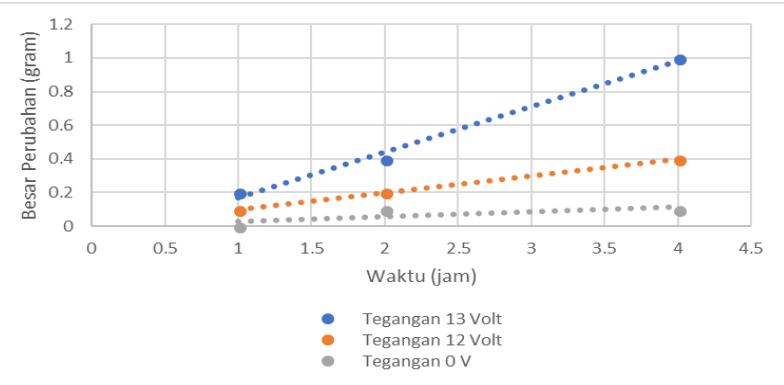

(a)

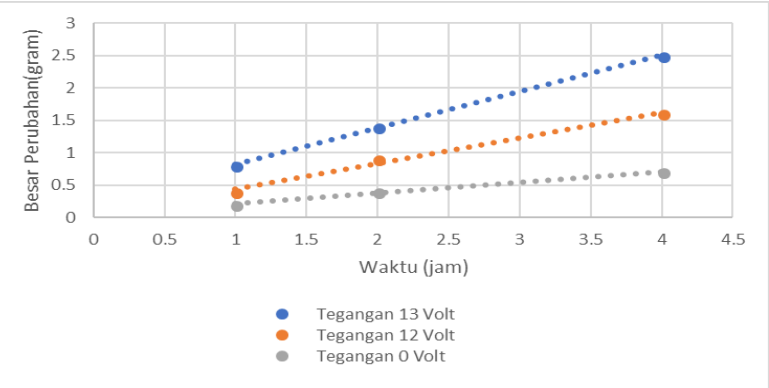

(b)

Gambar 7. Hasil Pengujian dengan Tegangan Sumber yang Berbeda terhadap: (a) Anggur, (b) Biji Coklat.

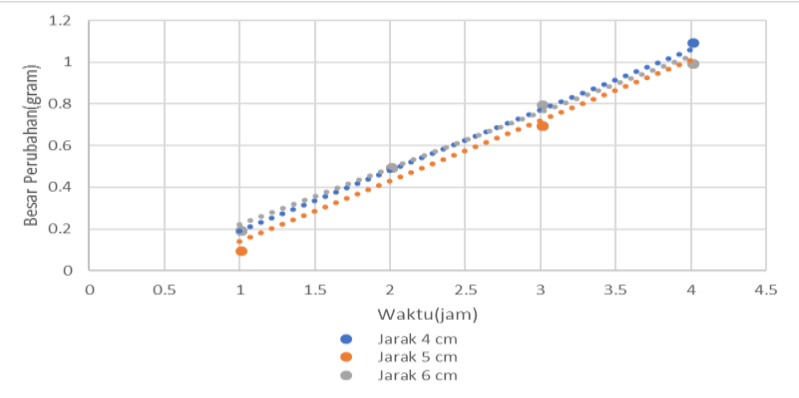

(a)

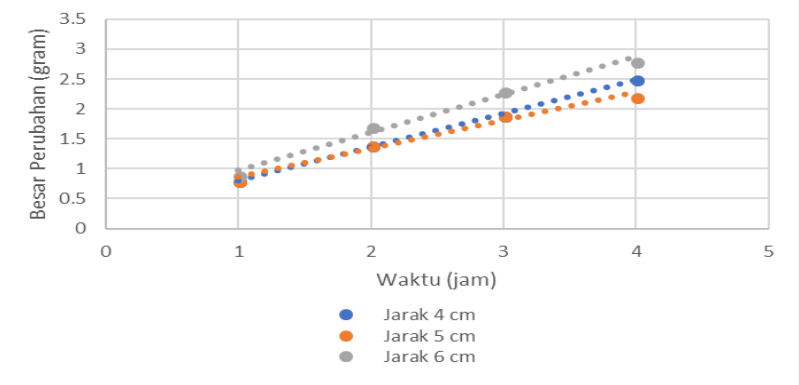

(b)

Gambar 8. Hasil Pengujian dengan Jarak Pengeringan yang Diubah terhadap: (a) Anggur, (b) Biji Coklat.

\section{B. Pengujian PWM Driver}

PWM pada pengujian ini akan diubah - ubah yang akan memberikan pengaruh terhadap pengeringan. Pengujisn terhadap PWM driver salah satunya yaitu pengujian pengeringan selama tiga jam dengan PWM bernilai $100 \%$, $75 \%, 50 \%$, dan $25 \%$. Hasil pengujian tersebut dapat dilihat pada Tabel 2 dan Tabel 3. Dari tabel-tabel tersebut, kecepatan pengeringan berada pada kondisi makismum pada PWM $100 \%$ dan akan berkurang siring dengan berkurangnya PWM. 


\section{Pengujian Kipas XFAN 80}

Pengujian dilakukan pada prototype dengan penempatan kipas yang berbeda. Posisi pertama yaitu digunakan kipas untuk melewatkan angin dari luar dan membuang udara yang ada di dalam ruang pengering. Sedangkan posisi kedua hanya menggunakan kipas pembuangan udara yang ada di dalam ruangan. Hasil pengeringan anggur dari kedua penempatan kipas tersebut dapat dilihat pada Tabel 4. Pengujian yang dilakukan juga dilakukan ketika tegangan kipas diubah ubah dan hasil dari pengujian tersebut dapat dilihat pada Gambar 9.

Tabel 2.

Hasil Pengujian Empat Nilai PWM dalam Waktu Tiga Jam terhadap Anggurr

\begin{tabular}{ccccc}
\hline \hline \multirow{2}{*}{ PWM } & \multicolumn{4}{c}{ Pengujian ke-(gram) } \\
\cline { 2 - 5 } & 1 & 2 & 3 & 4 \\
\hline $100 \%$ & 0,6 & 0,6 & 0,5 & 0,6 \\
$75 \%$ & 0,4 & 0,3 & 0,4 & 0,4 \\
$50 \%$ & 0,2 & 0,3 & 0,3 & 0,3 \\
$25 \%$ & 0,2 & 0,2 & 0,2 & 0,2 \\
\hline \hline
\end{tabular}

Hasil dari pengujian dengan posisi kipas yang berbeda menunjukkan kemiripan sehingga posisi kipas tidak terlalu mempengaruhi proses pengeringan. Namun, jika di lihat pada grafik hasil pengeringan anggur dengan nilai tegangan kipas yang berbeda, ketika kipas tidak diaktifkan pengeringan lebih cepat dengan nilai temperatur dan kelembapan dalam waktu satu jam.

Tabel 3.

Hasil Pengujian Empat nilai PWM dalam Waktu Tiga Jam terhadap Biji Coklat

\begin{tabular}{ccccc}
\hline \hline \multirow{2}{*}{ PWM } & \multicolumn{4}{c}{ Pengujian ke-(gram) } \\
\cline { 2 - 5 } & 1 & 2 & 3 & 4 \\
\hline $100 \%$ & 2,3 & 2,3 & 2,3 & 2,3 \\
$75 \%$ & 1,6 & 1,6 & 1,5 & 1,6 \\
$50 \%$ & 1,5 & 1,4 & 1,4 & 1,4 \\
$25 \%$ & 0,8 & 0,8 & 0,7 & 0,7 \\
\hline \hline
\end{tabular}

\section{D.Pengujian Load Cell}

Sebelum digunakan ke dalam sistem, load cell terlebih dahulu dikalibrasi dengan cara menimbang benda yang beratnya diketahui dan mencatat nilai hasil pembacaan ADC. Hasil pembacaan tersebut dapat dilihat pada Tabel 5 . Kemudian dari data tersebut ditentukan persamaan berat terhdapat pembacaan ADC dan diuji ulang pembacaan load cell. Pembacaan ADC yang sudah dikalibrasi dapat dilihat pada Tabel 6. Ketika pemanas diaktifkan, terjadi perubahan pembacaan terhadap load cell akibat perubahan panjang pada strain gauge sehingga nilai resistansi seperti pada Gambar 10.

\section{E.Pengujian Kontrol Proportional}

Pengujian propotional dilakukan dengan memberikan beban sementara pada platform. Kemudian seiring dengan berjalannya waktu, beban tersebut diturunkan beratnya. Pada Tabel 7 diambil data pengujian dengan nilai $\mathrm{Kp}=2,35$ dan diberikan set point anggur. Semakin besar pengurangan berat beban, semakin kecil pula PWM yang terbangkit.
Kemudian dilakukan tunning dengan aturan ZieglerNichols sehingga didapat nilai penguatan proportional $\left(\mathrm{K}_{\mathrm{p}}\right)$ yang ditentukan oleh nilai $\mathrm{L}$ dan $\mathrm{T}$. Nilai $\mathrm{L}$ dan $\mathrm{T}$ yang didapatkan pada Gambar 11 yaitu 6326,77 detik dan 34424,08 detik sehingga nilai $K_{p}$ sebesar 5,42.

Tabel 4.

Hasil Pengeringan Anggur dan Biji Coklat

\begin{tabular}{ccccc}
\hline \hline \multirow{2}{*}{$\begin{array}{c}\text { Waktu } \\
\text { (jam) }\end{array}$} & \multicolumn{4}{c}{ Perubahan Berat (gram) } \\
\cline { 2 - 5 } & \multicolumn{2}{c}{ Posisi Kipas 1 } & \multicolumn{2}{c}{ Posisi Kipas 2 } \\
\cline { 2 - 5 } & Percobaan 1 & Percobaan 2 & Percobaan 1 & Percobaan 2 \\
\hline 1 & 0,1 & 0,1 & 0,1 & 0,1 \\
2 & 0,2 & 0,2 & 0,3 & 0,2 \\
\hline \hline
\end{tabular}

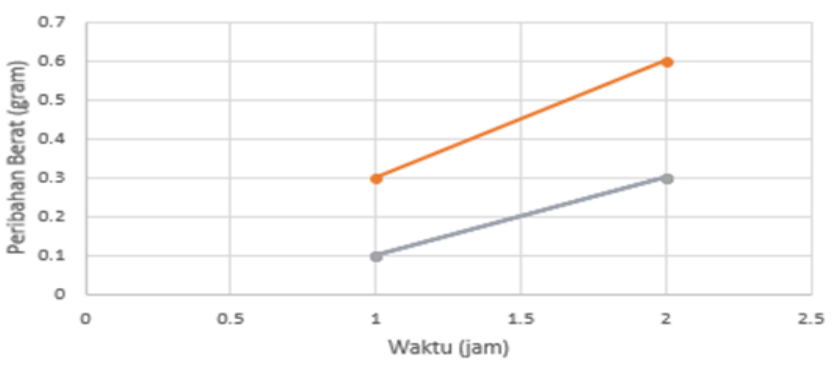

- tegangan ov -

Gambar 9. Hasil Pengeringan dengan Nilai Tegangan Kipas Diubah-ubah terhadap Anggur

Tabel 5.

Data ADC dari Beberapa Benda

\begin{tabular}{cc}
\hline \hline Berat Benda (gram) & Berat yang Terbaca dalam ADC \\
\hline 34,5 & 3882 \\
24,3 & 2734 \\
11,7 & 1315 \\
7,7 & 844 \\
\hline \hline
\end{tabular}

Tabel 6.

Hasil Pembacaan Berat Benda dengan Persamaan yang Telag Diketahui

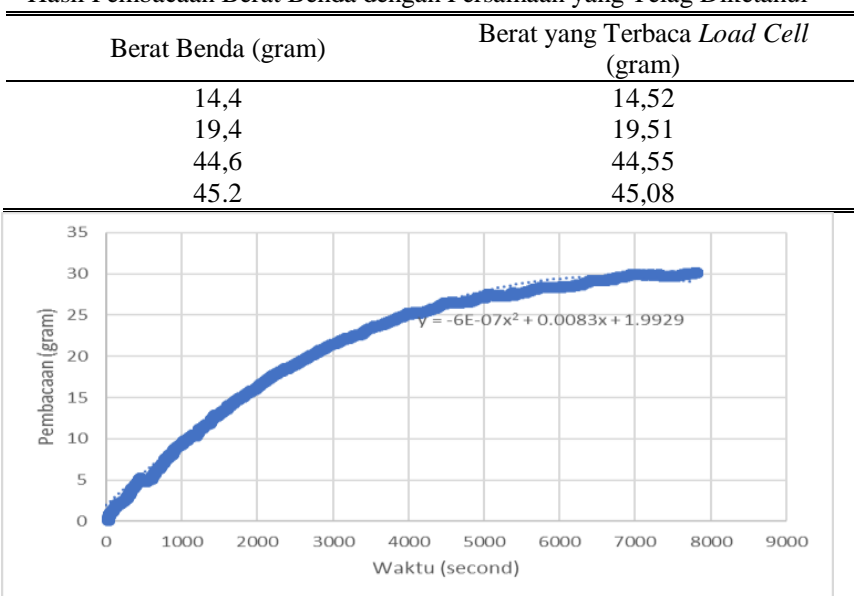

(a)

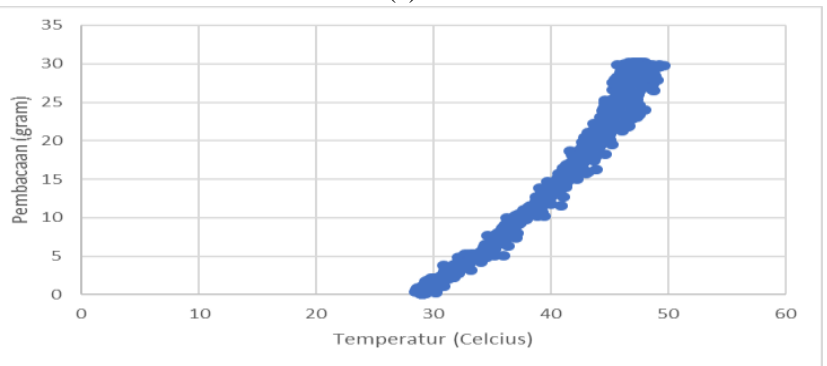

(b) 
Gambar 10. Pembacaan Load Cell ketika Pemanas Diaktifkan: (a) Perubahan terhadap Waktu, (b) Perubahan terhadap Temperatur.

Tabel 7.

Hasil Pengujian Sistem Propotional dengan $\mathrm{K}_{\mathrm{p}}=2,35$, set point anggur dan berat awal 26,88 gram

\begin{tabular}{ccc}
\hline \hline Duty Cycle & ADC dari PWM & $\begin{array}{c}\text { Berat Terbaca } \\
\text { (gram) }\end{array}$ \\
\hline $100 \%$ & 255 & 26.88 \\
$100 \%$ & 255 & 26.92 \\
$100 \%$ & 255 & 26.88 \\
$100 \%$ & 255 & 26.52 \\
$99,2 \%$ & 253 & 24.49 \\
$95,3 \%$ & 243 & 24.03 \\
$90,6 \%$ & 231 & 23.5 \\
\hline \hline
\end{tabular}

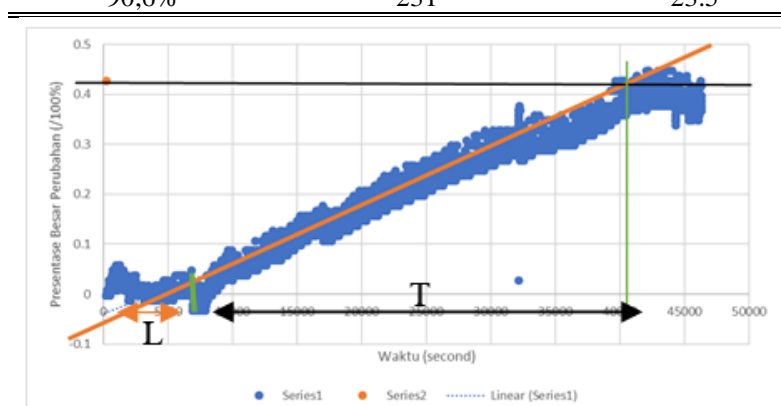

Gambar 11. Menentukan Nilai L dan T dari Grafik Masukan Set Up Biji Coklat.

\section{F. Pengujian Sistem Keseluruhan}

Pengujian sistem keseluruhan merupakan pengujian terhadap seluruh rangkaian terutama LED bank, load cell, dan LM35D. Pembacaan dari load cell dan LM35D akan memberikan masukan ke dalam kontrol proporsional dan memberikan keluaran berupa penguatan terhadap nilai PWM. Hasil dari pengujian tersebut dapat dilihat pada Gambar 11 dan

4.7. Kemudian dilakukan pengecekan untuk membandingkan pengurangan kadar air sesuai dengan set point dengan persamaan matematika dan alat ukur.

$$
\begin{aligned}
\text { Presentase kandungan air yang hialng dalam anggur } & =\frac{132,2-80}{132,2} \times 100 \% \\
& =39,5 \% 6
\end{aligned}
$$

Presentase kandungan air yang hilang dalam biji collat $=\frac{131-75,1}{131} \times 100 \%$

$$
=42,79 \%
$$

Jika hasil perhitungan dibandingkan dengan set point yang diketahui maka untuk anggur memiliki eror sebesar 10,5\% dan biji coklat memiliki eror sebesar $0,3 \%$ dengan nilai penguatan proportional yang sama. Sedangkan untuk pengukuran menggunakan alat pengukur kelembapan, pembacaan kelembapan anggur sebelum dikeringkan yaitu $68 \%$ dan hasil dari pengeringan yaitu $41 \%$ serta pembacaan kelembapan biji coklat sebelum dan sesudah dikeringkan yaitu $62 \%$ dan $8,5 \%$. Dari hasil pengujian, hasil dari alat pembacaan kandungan air memiliki pembacaan yang kurang sesuai dengan pengeringan terutama anggur. Bentuk akhir dari protype sistem pengering ini dapat dilihat pada Gambar 13.

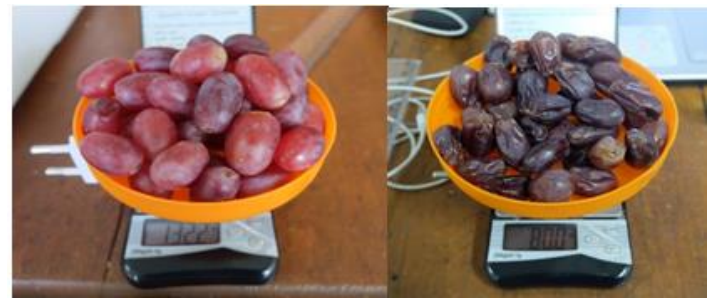

(a)

Gambar 12. Hasil Pengertian Sistem Kontrol terhadap Anggur: (a) Sebelum, (b) Sesudah.

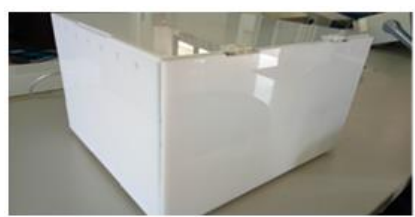

(a)

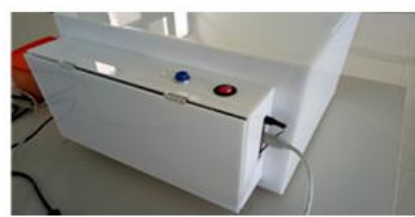

(b)
Gambar 13. Realisasi Akhir Prototype Sistem Pengering.

\section{KESIMPULAN/RINGKASAN}

Hasil dari penelitian ini yaitu pengeringan tercepat dialami oleh biji coklat karena tebal objek yang dikeringkan lebih rendah dibandingkan dengan anggur. Untuk kalibrasi load cell, hasil pengujian menunjukkan adanya rentang error pembacaan yaitu mendekati 0,8 gram. Hasil pengujian dari alat pembacaan pengering dengan persamaan perhitungan kandungan air memiliki perbedaan yang kurang tepat terutama pada anggur. Kandungan air yang hilang pada anggur dengan menggunakan persamaan yaitu 39,5\% dan dengan menggunakan alat pembaca kelembapan yaitu $27 \%$. Sedangkan kandungan air yang hilang pada biji coklat ketika menggunakan persamaan dan alat pembaca kelembapan yaitu $42,7 \%$ dan $53,5 \%$. Selain itu, penggunaan daya dari sistem pengering ini tidak terlalu besar yaitu sebesar 31,72 Watt

\section{DAFTAR PUSTAKA}

[1] Sabarella, "Analisis Kinerja Perdagangan Kakao," Pusat Data dan Sistem Informasi Pertanian Kementrian Pertanian 2016, Jakarta, 2016.

[2] V. J. Siaigian, “Outlook Kakao," Pusat Data dan Sistem Informasi Pertanian Kementrian Pertanian 2016, Jakarta, 2016.

[3] Subdirektorat Statistika Hortikultura, "Statistik Tanaman Buah-buahan dan Sayuran Tahunan Indonesia 2015," Badan Pusat Statistik Indonesia, Jakarta, Oktober 2016.

[4] A. Nadee, Y. Tirawanichakul, and S. Tirawanichakul, "Drying kinetics model and physical properties of herb Pandanus leaf," in Humanities, Science and Engineering (CHUSER), 2011 IEEE Colloquium on, 2011, pp. 54-59.

[5] L. Zhang and X. Wang, "Progress of internal, external structure and quality change of fruits and vegetables during infrared drying process," in New Technology of Agricultural Engineering (ICAE), 2011 International Conference on, 2011, pp. 1077-1082.

[6] M. Tasumi and A. Sakamoto, Eds., Introduction to experimental infrared spectroscopy: fundamentals and practical methods. Chichester: Wiley, 2015.

[7] K. Krishnamurthy, H. K. Khurana, J. Soojin, J. Irudayaraj, and A. Demirci, "Infrared heating in food processing: an overview," Compr. Rev. Food Sci. Food Saf., vol. 7, no. 1, pp. 2-13, 2008.

[8] R. Zurawski, Ed., Industrial communication technology handbook, Second ed. Boca Raton: CRC Press, 2015. 
[9] R. K. Sadar, A. M. Someshwar, and R. P. Chaudhari, "Load cell based cross verification of packaging material," in I-SMAC (IoT in Social, Mobile, Analytics and Cloud)(I-SMAC), 2017 International Conference on, 2017, pp. 460-463.

[10] W. Boyes, Ed., Instrumentation reference book, 4. ed. Burlington, Mass.: Butterworth-Heinemann, 2010.

[11] J. Fraden, Handbook of modern sensors: physics, designs, and applications, 3. ed., [Nachdr.]. New York, NY: AIP Press, Springer, 2004.

[12] P. D. Wijaya, M. Rivai, and T. Tasripan, "Rancang Bangun Mesin Pemotong Styrofoam 3 Axis Menggunakan Hot Cutting Pen dengan Kontrol PID," J. Tek. ITS, vol. 6, no. 2, pp. A766-770, 2017.
[13] F. Winjaya, M. Rivai, and D. Purwanto, "Identification of cracking sound during coffee roasting using neural network," 2017, pp. 271-274.

[14] N. Arsyistawa, M. Rivai, and S. Suwito, "Aplikasi Wireless Sensor Network Untuk Pembacaan Meteran Air," J. Tek. ITS, vol. 6, no. 2, pp. A762-765, 2017.

[15] M. S. Ramadhan and M. Rivai, "Sistem Kontrol Tingkat Kekeruhan pada Aquarium Menggunakan Arduino Uno," J. Tek. ITS, vol. 7, no. 1, Mar. 2018.

[16] D. I. Pratiwi and J. A. R. Hakim, "Rancang Bangun Deteksi Jalur Pipa Terpendam Menggunakan Mobile Robot dengan Metal Detector," vol. 6, no. 1, p. 7, 2017. 